\title{
VALUE CHAIN ANALYSIS OF TEFF IN EAST WOLLEGA, ETHIOPIA
}

\author{
Temesgen Kabeta ${ }^{1}$, Jema Haji ${ }^{2}$, Rijalu Negash ${ }^{3 凶}$ \\ ${ }^{1}$ Gambella University, Ethiopia \\ ${ }^{2}$ Haramaya University, Ethiopia \\ ${ }^{3}$ Jimma University, Ethiopia
}

\begin{abstract}
This study attempted to analyze the teff value chain in the Jimma Arjo District of East Wollega Zone, Western Ethiopia. The multistage sampling technique was employed to draw a sample of 123 teff producers, purposively selected 55 traders and 15 consumers. Both quantitative and qualitative data were collected from primary and secondary sources using pre-tested structured questionnaires and checklists. Descriptive statistics and Kendall's coefficient of concordance were applied to analyze data. Results showed that the main teff value chain actors in the study area included input suppliers, producers, local collectors, wholesalers, retailers, and consumers. In the district, there were no proper upgrading practices and governance systems in the teff value chain. The predicted probability that teff producers choose local collectors, wholesalers, retailers, and consumer outlets amounted to $45 \%, 69.9 \%, 20.4 \%$, and $74.6 \%$, respectively. Kendall's coefficient of concordance (W) analysis showed that $68.5 \%$ and $46.2 \%$ of farmers agreed with each other on the ranking of constraints hindering teff production and marketing, respectively. Recommendations drawn from the study findings include the need to improve the input supply system and governance, eliminate issues found in the chain, train farmers, enhance the quality of market information, boost teff productivity and volume sales, strengthen the links between teff value chain actors, and improve support institutions.
\end{abstract}

Keywords: constraints, governance, Jimma Arjo, Kendall's coefficient of concordance, teff value chain, upgrading

\section{INTRODUCTION}

A value chain is crucial in enforcing standards, with each actor ensuring that the product originating from the previous stage meets the criteria. According to Bekabil et al. (2011), the teff value chain program helps to double teff production. It ensures that farmers have access to sufficient markets to capture the highest value for their product. It also increases incomes and reduces the price paid by consumers within five years.

In Ethiopia, land used for teff production during the 2017 production year was estimated at 3.02 million hectares, and 50.2 million quintals were produced with the productivity of 16.64 quintals per hectare of land. In Oromia Regional State, $441,029.78$ hectares of land were allocated for teff production, and 24.74 million quintals of teff were produced with productivity of 17.17 quintals per hectares of land. In Eastern Wollega Zone, 77,455.03 hectares of land were used for teff production, and 1.4 million quintals of teff were produced with productivity of 18.02 quintals per hectare of land (CSA, 2017).

In Jimma Arjo District, there are 11,995 farm households, and among those, 7,512 (with 6,783 and 729 male and female household heads, respectively) are teff producers. Land allocated for teff production during the year (2017) was 4,630 hectares (16.54 percent of total land holdings) from 27,991 hectares of land. In the district, 56,717 quintals of teff were produced during the

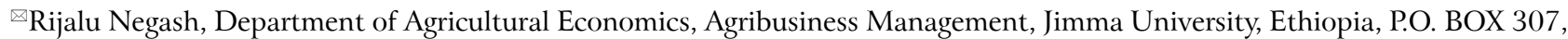
e-mail: rijalunegash@yahoo.com, https://orcid.org/0000-0002-1757-8584
} 
current production year, and teff productivity was 12.25 quintals per hectare of land, which was below the national standard (BoDANR, 2017). In light of the above information, this study focused on identifying actors and their respective functions, governance of teff value chain, identifying upgrading practices within the chain, and identifying and prioritizing teff production and marketing constraints in the study area.

According to the World Bank (2013), because African countries have quickly developing economies, agriculture is central to their development plans, and efforts have been made to link production with agribusiness for better growth in agriculture. Nowadays, it earns an average of 24 percent of its annual growth from farmers, and their crops value chains reveal common and well-known constraints, such as poor infrastructure; fragmented and risky markets; poorly functioning input markets; difficulties accessing land, water, and finance; and inadequate skills and technology. More revealing, however, are the significant differences across value chains.

Efa et al. (2016) showed that teff value chain upgrading practices employed by teff farmers included using improved seed and differentiating the product by color to meet the consumer demand. Teff traders entirely determine teff price and standard. Teff farmers' production and marketing constraints included shortages of fertilizer and seed supply, price setting, and insufficient access to credit, whereas those of teff traders included double taxation, insufficient infrastructure, capital shortage, inadequate credit service, farmers' reluctance to sell teff, lack of demand, scarcity of storage facilities and lack of government support.

The study area is known for teff production, mainly for market and family consumption. The supply of teff in the study area is subjected to a seasonal variation, with a surplus during harvest being its main feature. Yet, there is no such study that tries to look into the whole spectrum of the teff value chain in the district, which encouraged the researcher to perform the necessary teff value chain analysis. Since teff is an economically and socially crucial crop in the study area, this study is designed to address the prevailing information gap on the proper understanding and identifying actors involved in the chain and their respective roles, governance and upgrading practices of smallholder farmers, identifying and prioritizing constraints on teff production and marketing in the study area.

\section{METHODS}

\section{Description of the study area}

Jimma Arjo is located in East Wollega Zone of the Oromia Region, $379 \mathrm{~km}$ west of Finfinne/Addis Ababa. It is bordered on the southwest by the Didessa River that separates it from the Bunno Beddele Zone, on the northwest by Diga Lake, on the northeast by Guto Wayu, and

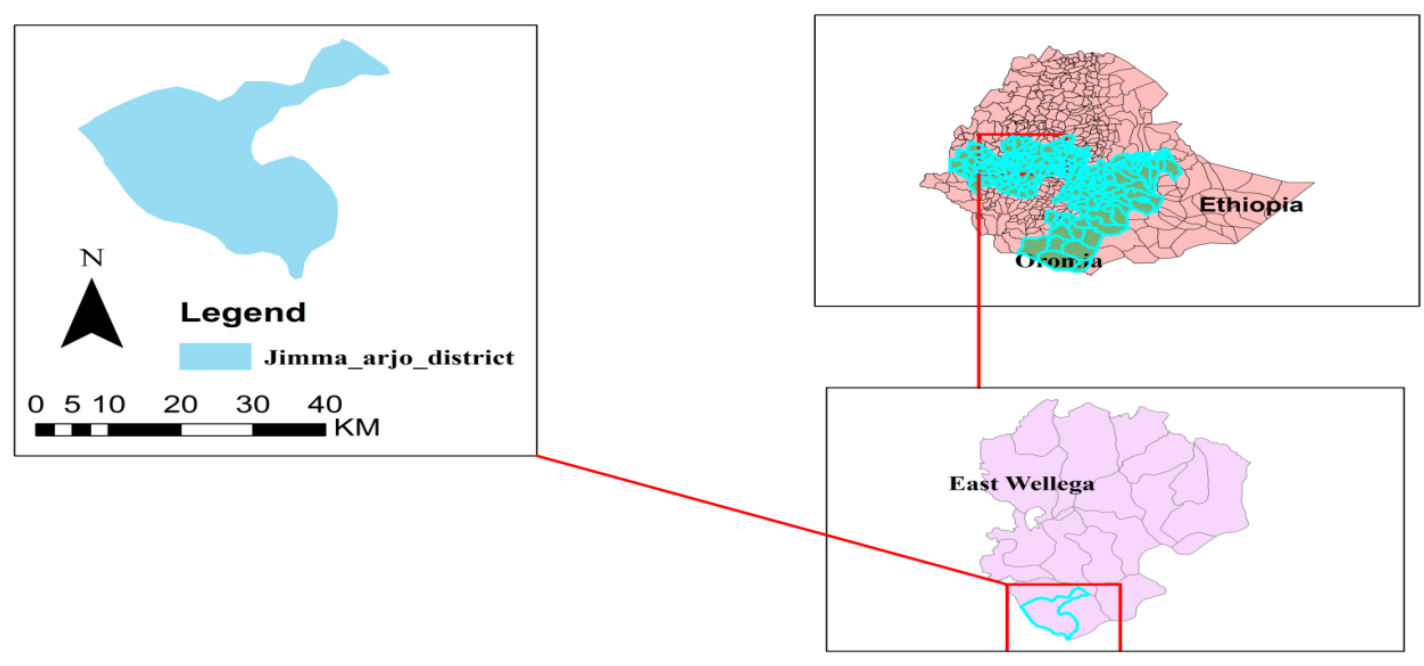

Fig. 1. GIS map of the study area

Source: www.arcgis.com 
southeast by Nunu Kumba District. The central part of the study area can be described as having rolling and undulating topography with a dendrite drainage pattern. The elevation of the study area ranges from 1500-2600 $\mathrm{m}$ a.s.l. The common physiographic features include mountain ridges, plateaus, and basins. According to the agro-climatic classification of Ethiopia, the relief/ landform of the study area can be grouped into three major physiographic units based on their elevation. The lowlands located $<1500 \mathrm{~m}$ a.s.l., which is suitable for maize, sorghum, sesame, noug, and Daguja production, mid-altitude of $1500-2300 \mathrm{~m}$ a.s.l., which is suitable for all types of crops, and highlands located $>2300 \mathrm{~m}$ a.s.l., which is ideal for teff, wheat, bean, pea, with $30 \%, 58 \%$, and $12 \%$ coverage, respectively.

The quantitative data were collected from the farmers via individual face-to-face interviews using a pretested interview schedule, while the qualitative data came from the focus group discussion and key informant interviews using checklists. The researcher has conducted the pilot study in administering the addition and deletion of the question in the interview schedule to maintain the research validity. Well-trained enumerators collected the data from the respondents.

Primary data sources included smallholder teff farmers interviewed randomly and purposively selected traders and consumers. Secondary data sources included district agriculture and rural development offices, primary cooperatives, district trade and industry offices, data obtained from CSA, published and unpublished materials either from the internet or bulletins.

Primary data: Data were collected formally by individual interviews using a pre-tested interview schedule, while data from focus group discussion and key informant interviews were collected using checklists. Before distributing the pre-tested interview schedule among enumerators, the author trained enumerators on collecting relevant data from relevant respondents.

Secondary data: Checklists were employed to collect data from published and unpublished materials, district agriculture and rural development offices, farmers' organizations, input suppliers, marketing agencies, primary cooperatives, district trade and industry offices.

\section{Sample size determination}

The multistage stages sampling technique was used to select sampled villages and respondents. There are 20 rural and two urban villages administrations in the district. From 20 rural village administrations, only 12 rural villages have teff producers. In the first stage, from 20 rural villages, 12 teff producing villages were selected purposively. In the second stage, from 12 teff producing villages, three villages were chosen randomly. In the third stage, 122 farmers from three sample villages were randomly selected based on probability proportional to size (PPS) sampling using the Yemane (1967) formula.

$$
n=\frac{N}{1+N(e)^{2}}
$$

where: $n=$ sample size, $\mathrm{N}=$ number of household heads of 12 teff producer kebeles (7512), and e = level of precision assumed 9\%. Sultan (2016) and Addisu (2016) also used this level of precision. Accordingly, the required sample size at $91 \%$ confidence level with a level of precision equal to $9 \%$ was used to obtain a sample size required, representing an actual population.

$$
n=\frac{2012}{1+2012(0.09)^{2}}=123
$$

Table 1. Sample distribution of producer kebeles (PPS)

\begin{tabular}{lccc}
\hline Selected kebeles & Total households & Proportion & Sample $(n)$ \\
\hline Hindhe & 880 & 0.44 & 53 \\
Tibe caffe & 506 & 0.25 & 31 \\
Hara & 626 & 0.31 & 38 \\
Total & 2012 & 1.00 & 122 \\
\hline
\end{tabular}

Source: own data computation, 2018.

Data from traders and consumers were also collected. Trader surveys were conducted in market towns and villages in which a satisfactory sample of teff traders existed. Based on the teff flow, three markets (Gaba Sanbata, Arjo, and Jimate) were selected as the main teff marketing sites in the study area. Thereby, 15 local collectors, 20 wholesalers, 20 retailers, and 15 consumers were selected.

\section{Methods of data analysis}

Descriptive statistics were employed to analyze the data collected from all actors involved in the teff value chain and marketing of this crop in the study area. 
Table 2. The input used for teff production and amount applied during the 2017 production year

\begin{tabular}{lccccc}
\hline \multicolumn{1}{c}{ The input used and its amount } & Sum & Mean & Std dev & Minimum & Maximum \\
\hline Quantity of DAP used for teff production in quintals & 94.96 & 0.78 & 0.64 & 0.13 & 4 \\
Quantity of UREA used for teff production in quintals & 82.77 & 0.69 & 2.26 & 0 & 3 \\
Amount (liters) of herbicides used for teff in 2017 & 93.15 & 0.76 & 0.89 & 0.13 & 8 \\
\hline
\end{tabular}

Source: own survey computation, 2018.

\section{Descriptive statistics}

Descriptive statistics such as mean, standard deviation, minimum, maximum, frequencies, and percentages were used. Kendall's coefficient of concordance (W) was also used to rank constraints hindering teff production, marketing, and agreement among farmers on such constraints.

\section{RESULT AND DISCUSSIONS}

\section{Input utilization}

Inputs used by farmers in the study area included fertilizer, DAP, UREA, and herbicides for teff production. These inputs are supplied to farmers either by cooperative/unions and private traders. Cooperatives are significant fertilizer suppliers for producers in the study area. The government (National Input Supply Enterprise) supplies the unions with such fertilizers as DAP and Urea. The unions can sell it to primary cooperatives, and the cooperatives distribute it to farmers and other private input suppliers. Moreover, using the recommended fertilizer application rate is vital to obtain the required production and marketable supply. However, farmers in the study area use varying fertilizer application rates, often below the expert-recommended rate, to cover their entire farmlands with little fertilizer quantity due to their financial constraints, which leads them to obtain a small amount of teff product per hectare/acre of land. It was found that 94.96 quintals of DAP and 82.77 quintals of UREA were used for teff production with a mean of 0.78 and 0.68 quintals used by each respondent farmers during the 2017 production year, respectively.

The amount of herbicide used by farmers during the year for teff weeding was 93.15 liters, with an average of 0.76 liters used by each sample household, as shown in Table 2. The other point is that farmers purchase those inputs from both cooperatives and private traders.
However, farmers prefer buying it from private traders to cooperatives due to price differences. Because those farmers produce small amounts of teff and use little inputs, they prefer to purchase agricultural inputs from traders because cooperatives sell in large quantities at prices beyond farmers' means, and buying less than half quintal is impossible.

Table 3. Suppliers of input to farmers

\begin{tabular}{lcc}
\hline \multicolumn{1}{c}{ Suppliers of input } & Frequency & Percent \\
\hline Cooperatives & 90 & 73.8 \\
Private & 32 & 26.2 \\
Total & 122 & 100.0 \\
\hline
\end{tabular}

Source: own survey computation, 2018.

Among sampled teff producer households, $73.8 \%$ purchase agricultural inputs from primary cooperatives /unions and $26.2 \%$ from private traders, as shown in Table 3 . In this case, primary cooperatives/unions were the major suppliers of input to teff producers because their prices are fairer than private traders', and fewer participate in the teff output market.

\section{Value chain analysis}

\section{Teff value chain actors and their functions in the study area}

Input suppliers: At this stage of the value chain, many actors are directly or indirectly involved in the study area's input supply. Currently, primary cooperatives/ unions and private input suppliers are the main input supply sources (see Table 3). The above-mentioned actors are responsible for providing seeds of improved varieties, fertilizer, and farm implements for the farmers in 
the study area. Mostly herbicides were supplied by private traders and cooperatives to farmers. Those primary cooperatives buy it from importers in Addis Ababa and resell it to farmers in the district. The purchased chemicals are transported by hired vehicles; public transport while other outlets do not use vehicles. The major buyers of herbicides include individual farmers and primary cooperatives. Suppliers set price plus commission to determine the market's selling price, but traders mostly steer prices using other methods than market forces or interaction between supply and demands.

Farmers/producers: There are smallholder teff producer households in the district, and there were no commercial teff farming or state farms involved in teff production because teff production is costly, yields small output per hectare when we compared to other cereal crops. It is also force effective because it has less quality compared to other areas; it is priced less because it is not pure white and only depends on natural rainfall, which means no irrigation is applied for its production as opposed to other crops. Farmers start with land preparation, produce, and store and provide a surplus to market. Teff producers in the district supply their products only for the district market. The study result indicated that all farmers sold within the district for different actors (local collectors, wholesalers, retailers, and consumers) because they are smallholders, and their average productivity is small and below the national standard of teff.

Local collectors: They play an essential role in collecting produce from smallholder farmers at the village market and delivering it to wholesalers, retailers and consumers at the district market. They are the first actor who links farmers to other actors involved in teff market. Local collectors purchase teff from farmers at village markets such as Gaba Sanbata, Jimate, and Gombo and resell it at the district market to wholesalers and consumers, earning profits through adding value by transporting, storing, and cleaning teff. Local collectors prefer to sell to consumers than other actors because consumers buy it from them at a higher price than traders. These actors own lower capital than other traders because they use profit earned from reselling teff products to provide for their families. When local collectors resell to consumers, the price is set by market interaction, but when reselling to wholesalers, there was a problem of scale cheating, and retailers demand lower prices than consumers. Local collectors resell only within the district market.
Wholesalers: They buy teff from individual farmers, some collectors/small traders, and a few other wholesalers within the district. They purchase this product only from actors within the district and resell within and outside the district market. They resell to consumers such as government workers, retailers, wholesalers, hotels, and injera sellers within the district. They add value by cleaning, loading/unloading, using vehicle transportation, and reselling it to outside zone markets such as Jimma, Agaro, Mettu, Mizan, and Tepi town retailers and wholesalers, and including commission, transport costs, and their profit. These actors play a major role in moving the product from one district or zone to another by using vehicle transportation. They are more capital efficient and have better access to credit services than other actors. Each of the wholesalers in the district was playing a crucial role in creating job opportunities for at least five people under a single wholesaler and generating income for the government through paying tax, which directly contributes to social welfare. They supply the product from surplus areas to shortage areas.

Retailers: They are market actors operating at the last stage of the marketing channels, selling to consumers. They buy teff from wholesalers and farmers in their neighborhoods and resell it directly to consumers. They perform several value addition activities such as buying, transporting, storing, and selling to end-users. During the survey, the problem raised by retailers was limited financial capacity that hinders them from being involved in a larger trade. They prefer to buy from farmers than other actors and not resell it to other actors than consumers.

Consumers: They include individual groups involved in buying teff products from farmers and traders for consumption, not for reselling. Consumers generally prefer to buy it from farmers than traders due to price differences and quality. They pay part of their income for buying teff, and those consumers in the district are traders themselves, government workers and prison houses, and consumers outside the district. Farmers and all traders preferred consumer outlets because consumer prices were higher than other prices and make fair decisions on price setting than any other actor. The above actors are directly involving in owning the resource and earning profit/income from marketing exchanges by adding value at each possible channel by producing, transporting, loading/unloading, cleaning, packaging, reselling, generating income, earning a profit, buying, and consuming teff products. 


\section{Teff value chain supporters and their functions in the study area}

Primary cooperatives: They play a crucial role in supplying inputs to the farmers. However, they are not efficient enough in terms of timely agricultural input provisions, buying harvested products, and financial management. In the study area, cooperatives are not efficiently participating in teff marketing. They are both direct and indirect actors in the teff value chain.

Bureau of District Agriculture and Natural Resources: This actor plays an important role in teff production and increasing the marketed surplus of teff to feed the rapidly growing population. This sector contributes to teff production by structuring, providing, and coordinating extension or development agents for each kebele households under their supervision. This organization provides training, adoption of new technologies of production, input in collaboration with cooperatives/ unions such as fertilizer, herbicides, improved seeds, and know-how to increase the productivity of this essential crop to raise farm income.

Oromia Credit and Saving Institution (OCSI): It is part of a microfinance institution that provides credit services for smallholder teff producers. It is a major financial service source to farmers and urban people, including assemblers and retailers, but not wholesalers because they can get credit from banks. It helps smallholders and financially inefficient actors to obtain finance. This institution also allows its users to save money given to them when they leave out their services. Not all farmers befit from this institution because farmers have insufficient knowledge about using money obtained from this institution for production rather than family consumption.

Banks: It is the predominant financial source for wholesalers, providing credit services in the long or short term. Most wholesalers in the district are getting credit service from this institution and from each other. It is the only source of credit for larger traders because they prefer huge capital for trading activities than retailers and local collectors. Also, it is a source of credit for cooperatives (input suppliers). But this sector is not providing credit service for smallholder farmers because they lack collateral assets. It does not operate in rural areas to finance this important crop for both the national economy and consumption.

Bureau of District Trade and Industry: It plays a major role in coordinating all private and cooperative/ union traders by providing licenses, training, collecting legal payments from traders to increase government revenue for public welfare. This organization coordinates and manages all teff traders in the district and works to create competent firms that sustainably create job opportunities for the next generation.

\section{Teff value chain map}

A value chain map is a standard tool of value chain research and analysis (ILO, 2009). This study identified actors, their functions, supporters, and financial flow between actors, information, input service flow, and product flow. The current value chain map of teff in Jimma Arjo District is depicted in the below figure. Finance, service, product, input, and information flows between each actor through buying and selling as well as giving credit and selling the product as a credit for each other, while product flows from one actor to others. However, the flow of information between actors in the study area was mapped using dash arrows because the flow of information between actors was inefficient.

Input and service flows were mapped by one arrow (one direction), indicating input flows from suppliers to farmers for production rather than further exchange activities. Service flows in one direction, especially from the District Bureau of Agriculture and Natural Resources. And also, the product flows in one direction in each channel from producer to consumer. The below map of the teff value chain in the study area also shows the respective functions of actors along the value chain. That means input suppliers provide input, and farmers produce and sell on the market, traders purchase teff from producers and resell or distribute it to next actors, while consumers purchase and consume it at the given price from his/her income.

\section{Governance of teff value chain}

Analyzing the existing business links includes judging the intensity and sustainability of cooperation, the existence of lead firms, and their attitude and commitment. A related point is analyzing conflicts arising from negotiation power differences, price setting and asymmetric information, and competition for resources between value chain actors. In the district, about $68.5 \%$ of producers accepted the price and product specification determined by the buyer, even though the price was lower than the average market price. About $25.8 \%$ of producers had to accept the price specified in negotiations with traders, 


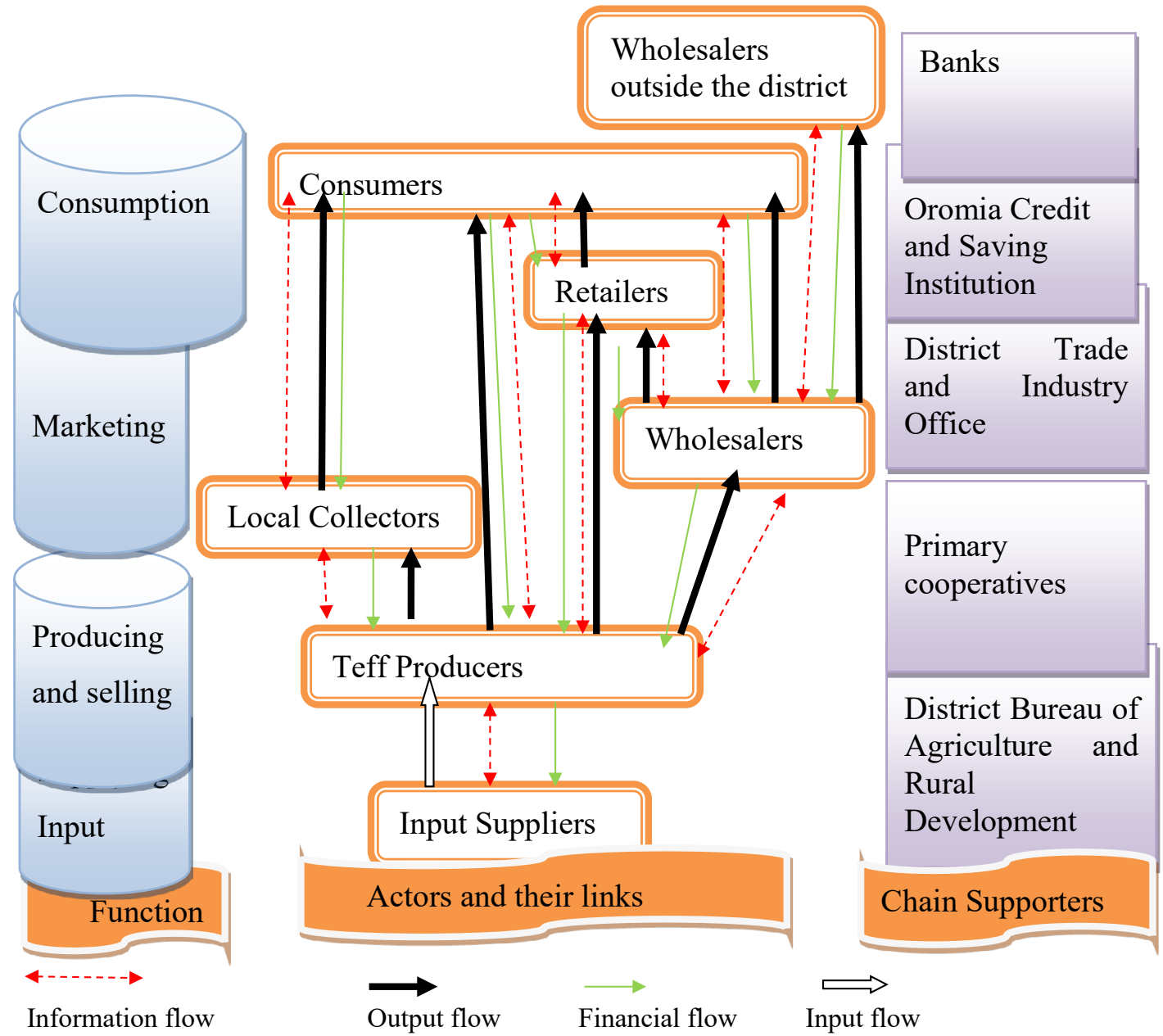

Fig. 2. Teff value chain map of the study area

Source: own data computation, 2018.

and the rest sold at a price set by them (farmers) (see Table 4). Those who sold their teff produce at a price they set always sold it to consumers and not other traders. It appears that the producers in the study areas have almost no bargaining power. This is due to the asymmetric information between all actors. Teff production in the study area is not driven by demand or buyers; it is a producer-driven production system. It means that teff products in the study area are cheap and have low prices and poor quality. What is more, the production structure is highly scattered, and there are few producers' organizations. Smallholder farmers are highly dependent on intermediaries to take their produce to the markets, which forces them to accept the price set by buyers.
There is buying and selling (transaction) but little exchange of information and learning from one another (interaction) in the teff value chain. This type of value chain governance is market-based relationships because the conditions of exchanging goods and services are based on the market price. It means that buyers (traders) govern the teff value chain while farmers are led by them in the study area and raised by focus group discussion. The survey result indicates that when the price of teff falls due to asymmetric information between farmers (sellers) and buyers (traders), farmers earn low prices for their teff products at the market center. In the study area, $21 \%, 42.7 \%, 12.9 \%$, and $21.8 \%$ of farmers, as shown in Table 4, faced the problem of taking the 
Table 4. Price determination

\begin{tabular}{llcc}
\hline \multicolumn{1}{c}{ Variables } & \multicolumn{1}{c}{ Responses } & Frequency & Percent \\
\hline Level of quality of market & Adequate information & 0.00 & 0.00 \\
information & Medium information & 57 & 46.0 \\
& Low information & 39 & 31.5 \\
& No information & 12 & 9.7 \\
Farmers' decision when teff price & Take it back home & 26 & 21.0 \\
falls at the market & Sell at a low price & 53 & 42.7 \\
& Sell at another market & 16 & 12.9 \\
& Put at a relative's house & 27 & 21.8 \\
Buyers' trust level in farmers & Very trusted & 17 & 13.7 \\
& Moderately trusted & 41 & 33.1 \\
& Little trusted & 64 & 53.2 \\
Do you have links to buyers & No & 85 & 68.5 \\
& Yes & 37 & 29.8 \\
Difficulties with getting buyers & No & 93 & 75.0 \\
& Yes & 29 & 23.4 \\
& Buyers & 85 & 68.5 \\
& Farmers & 5 & 4.0 \\
& Negotiations & 25.8 \\
\hline
\end{tabular}

Source: own survey design, 2018.

product back home, sold at a low price, sold at another market, or put at a relative's house, respectively.

Based on the quality of information transmitted from buyers/other sources about the price of teff to suppliers, there was a problem of farmers not obtaining adequate information on the teff price in the district. And only $46 \%, 31.5 \%$, and $9.7 \%$ of farmers got medium, or low levels of information and no information, respectively, concerning the price of teff. This shows there is a problem of asymmetric information indicated in Table 4.

The survey result also indicated that the farmers took the teff product to market based on information obtained from different sources such as neighbors, traders, radio, and other means. About $23.4 \%$ of sampled respondents faced difficulties finding teff product buyers, forcing them to sell their product at a low price or otherwise put it at a relative's house or transfer the product to another market, in which case farmers incur additional transportation cost (see Table 4). When the transaction takes place between actors at different stages of the value chain, it is called vertical linkages. The farmers' links to buyers of their teff product are vertical. However, the survey result showed that only $29.8 \%$ of the farmers had connections to teff product buyers from the district. Horizontal business linkages refer to the transactions between actors of the value chain (enterprise) operating in the same functional segment of the value chain. In the study area, because all farmers are smallholders, they are not linked that much horizontally, and their integration is not powerful. This implies that there are weak links among the teff producers in the study area.

To say one commodities market is competitive, there should be a better flow of information between actors involved in that market and good trust. Information was found to flow from buyers, through their agents and/or brokers, to the farmers. Out of the total district sample, 
$13.7 \%, 33.1 \%$, and $53.2 \%$ of the buyers' trust levels concerning farmers indicated that farmers were highly, moderately or little trusted, respectively, because most of the time, traders cheat on weight scaling and hide the exact price of teff per kilogram as shown in Table 4. This indicates that most farmers are not trusted by the buyers and prefer to set prices through negotiation and check the exact weight of their crop.

A high disintegration characterizes the teff value chain in the study areas. Generally, there was weak integration between teff traders and producers in the study area because farmers were less trusted with a price set by traders for teff produce. There was also an information gap concerning the end price of teff between producers and farmers, which causes negative vertical integration between all teff value chain actors and leads farmers to earn less profit share compared to other actors. According to the focus group and key informant respondents, traders benefitted more from teff sales than producers because farmers pay production costs, which are counted in monetary terms but overlooked, while traders incur only short-time costs concerning transportation, brokers, storage, taxation, and loading/ unloading.

\section{Value chain upgrading}

In the district, some of the sampled producers engaged in product upgrading activities. The below table summarizes some of the changes or improvements made to the product. These changes include using fertilizer to increase production, diversification, changing types of seed, applying herbicides, and differentiation. All producers used local seed for teff production, which means no farmer used improved teff seed because of no supply. The use of improved seed and fertilizer by smallholder producers may be considered product and process upgrading, which introduces new products and increases the efficiency of the internal process for production.

In the study area, all sampled respondents used fertilizer and herbicides to increase teff productivity because their land is much degraded and highly infertile; it is the case for weed planting (see Table 5). When we compare the current teff productivity with previous years, it is significantly decreasing and needs immediate solution or policy intervention. Because teff price depends on color, farmers produce red, mixed, and white teff simultaneously. In the district, $94.26 \%$ of teff farmers diversified teff production, while $5.74 \%$ did not, by color
$(59.2 \%)$, by purifying sand materials $(21.5 \%)$ or types of seed (13.1\%). Most farmers used white teff for marketing because its price is higher than mixed and red teff, while farmers used red and mixed teff for family consumption and marketing. In the district, teff products have less quality, with no market demand at Finfinne (the capital of Oromia Region, Ethiopia) but supplied to Mettu, Jimma, Agaro, Tepi, Beddele, and Mizan wholesaler and retailer markets by district traders.

Table 5. Upgrading activity performed by teff producers

\begin{tabular}{|c|c|c|c|}
\hline Variables & Responses & Frequency & Percent \\
\hline Types of seed used & Local seed & 122 & 100 \\
\hline Using fertilizer & Yes & 122 & 100 \\
\hline Using weed killer & Yes & 122 & 100 \\
\hline \multirow{2}{*}{$\begin{array}{l}\text { Differentiating } \\
\text { production }\end{array}$} & Yes & 115 & 94.26 \\
\hline & No & 7 & 5.74 \\
\hline \multirow{3}{*}{$\begin{array}{l}\text { Ways of } \\
\text { differentiating }\end{array}$} & By color & 77 & 59.2 \\
\hline & $\begin{array}{l}\text { By Purity of product } \\
\text { from sand materials }\end{array}$ & 28 & 21.5 \\
\hline & $\begin{array}{l}\text { Types of seed (im- } \\
\text { proved, local) }\end{array}$ & 17 & 13.1 \\
\hline
\end{tabular}

Source: own data computation, 2018.

Upgrading entails not only improvements in products but also investments in people, knowledge, processes, equipment, and favorable work conditions. Farmers in the district are still upgrading teff production less efficient because of a shortage of input supply and inadequate extension services, provided that the producer is not competent and producing less than the national standard of teff productivity and below the district office of agriculture plan. Due to insufficient upgrading activities concerning teff production in the district, it was less priced and had low demand than other crops. Concerning quality, many teff production stakeholders in the district raised the problem of low teff quality, which leads to a low level of trust between teff value chain actors. Generally, in the district, no upgrading is done concerning marketing, functions, the interaction between actors, improving win-win strategies, poor participation, and the way the teff market is functioning is not competent. 


\section{Constraints on teff production and marketing in the study area}

Several factors affect agricultural productivity in general and teff production in particular in the district. These include high rainfall during harvest, shortage of rain during production, teff rust during harvesting, high input price, inadequate extension services, and credit provision, shortage of cultivable land, low soil fertility, lack of capital, shortage of improved seed supply, and low yield of teff per hectare. Kendall's coefficient of concordance (W) analysis showed that $68.5 \%$ of farmers agreed with each other on the ranking of the above teff production constraints (see Table 6). Heavy rainfall during yield was found to be the critical constraint on teff production in the district. Teff producers indicated this problem as a major issue they faced during harvesting. They lost huge quantities of teff produce because during harvesting, frequent rainfall damages teff yield and results in farmers getting lower the expected output for a long time.

The study result showed that teff rust during harvesting, low yield per acre of land, shortage of rain during production, high input price, inadequate extension services, insufficient credit provision were indicated by producers and ranked as the second, third, fourth, fifth, sixth and seventh most important constraints following too high rainfall. Teff rust was found to be a major constraint hindering teff production in the district because it destroys the yield, which directly reduces the productivity of this vital crop. This problem was also limiting farmers' ability to enhance their food security and supply teff produce for the market. The low yield of teff per acre of land was also found to be among major constraints hindering farmers because of different factors such as high rainfall during harvesting and inappropriate harvesting technique.

Shortage of rainfall during production was also found to be much more than a minor problem of teff production in the study area. This constraint reduces teff productivity and leads farmers to earn less than national, regional, zonal, and district standards. Next to this constraint, high input price is also raised by farmers as a significant issue that needs serious corrections to enhance teff productivity. In the study area, high input price leads farmers to produce a small amount of teff because fertilizer, herbicides, wages, land rent, and seed prices increase from year to year. Inadequate extension service also limited farmers' ability to produce teff in large quantities for both family consumption and market supply; it was ranked sixth after too high input price. It is evident that the provision of extension service has a significant role in increasing this important crop's productivity to sustain food security and increase the amount of teff supplied to the market. However, in the study area, the concerned offices were not functioning well as expected, and there were problems of good governance, leading to limited teff production in the district.

Table 6. Ranking of constraints on teff production agreed on by responders

\begin{tabular}{lcc}
\hline \multicolumn{1}{c}{ Constraints listed } & $\begin{array}{c}\text { Mean } \\
\text { ranking }\end{array}$ & $\begin{array}{c}\text { Overall } \\
\text { ranking }\end{array}$ \\
\hline High rainfall during harvesting & 4.96 & $1^{\text {st }}$ \\
Teff rust during harvesting & 5.05 & $2^{\text {nd }}$ \\
Low yield per acre of land & 5.09 & $3^{\text {rd }}$ \\
Shortage of rainfall during & 5.52 & $4^{\text {th }}$ \\
production & & \\
High input price & 5.59 & $5^{\text {th }}$ \\
Inadequate extension service & 5.61 & $6^{\text {th }}$ \\
Insufficient credit provision & 5.61 & $6^{\text {th }}$ \\
Low soil fertility & 6.55 & $7^{\text {th }}$ \\
Shortage of cultivable land & 6.65 & $8^{\text {th }}$ \\
Lack of capital & 7.78 & $9^{\text {th }}$ \\
Lack of improved seed & 7.58 & $10^{\text {th }}$ \\
\hline
\end{tabular}

$\mathrm{N}=122$, Kendall's $\mathrm{W}=0.685$, Chi-square $\left(\mathrm{X}^{2}\right)=459.82$, $\mathrm{DF}=10$, Asymp.sig. $=0.000$

Source: own data computation, 2018.

Insufficient credit service was also found to be a major problem of teff production in the study area and ranked next to inadequate extension service. Farmers raised the issue of credit provision because concerned organizations were not providing enough credit services for farmers. And the way they provide them also needs serious correction because farmers have limited access to credit due to different collateral problems and fear of repaying the credited money with interest rates. Low soil fertility was also seen as a serious problem because it significantly reduces teff productivity from year to year and leads farmers to incur growing production 
expenses. This problem occurred due to land degradation because farmers were plowing their land continuously without shifting cultivation. Shortage of cultivable land was another major problem of teff production in the study and ranked next to low soil fertility. Next to this constraint, the capital shortage hindered teff productivity because it is an economic resource required to combine farmers' resources such as land, family labor, and managerial skills of farmers. There was no supply of improved seed in the study area, and farmers used local varieties repetitively, leading to a productivity decrease compared to the previous years.

\section{Constraints on teff marketing}

A number of factors affect teff marketing in the district, including price fluctuations, low bargaining power of producers, low teff price, weak links between farmers and traders, low teff quality, lack of market information, and farmers' mistrust of teff traders. Kendall's coefficient of concordance (W) analysis showed that $46.2 \%$ of farmers agreed with each other on ranking the constraints on teff marketing (see Table 7). The main limitations were explained by price fluctuation being a major constraint hindering teff marketing and ranked first in the study area. In the study area, teff prices fluctuated seasonally, leading farmers to earn minimum income from teff sales.

Low bargaining power, low teff price, teff quality, weak links between farmers and traders, lack of market information, and buyers' mistrust of farmers consisted of marketing constraints ranked the second, third, fourth, fifth, sixth, and seventh, respectively. Low bargaining power was also the second constraint on teff marketing in the district, hindering farmers from earning the minimum income on the sale of their products and a small contribution to enhancing food security and reducing the amount of teff supplied to the market in the study area. Despite the considerable constraints listed above, there are many opportunities for teff marketing in the district. These potential opportunities included urbanization and industry or factories in the district, increasing the demand for teff. Naturally, the increased demand would be followed by better farm prices for producers. As a result, farmers would have an incentive to expand their output.

Furthermore, the rising population around Arjo town is creating additional demand for agricultural commodities like teff. Consequently, this contributes to the
Table 7. Ranking constraints hindering teff market in the district

\begin{tabular}{lcc}
\hline \multicolumn{1}{c}{ Constraints listed } & $\begin{array}{c}\text { Mean } \\
\text { ranking }\end{array}$ & $\begin{array}{c}\text { Overall } \\
\text { ranking }\end{array}$ \\
\hline Price fluctuation & 3.16 & $1^{\text {st }}$ \\
Low bargaining power of producers & 3.25 & $2^{\text {nd }}$ \\
Low teff price & 3.82 & $3^{\text {rd }}$ \\
Weak links between farmers and traders & 4.06 & $4^{\text {th }}$ \\
Low teff quality & 4.07 & $5^{\text {th }}$ \\
Lack of market information & 4.80 & $6^{\text {th }}$ \\
Buyers' mistrust of farmers & 4.84 & $7^{\text {th }}$ \\
\hline
\end{tabular}

Kendall's $\mathrm{W}^{\mathrm{a}}=.426$, Chi-square $=328.24, \mathrm{df}=6$, and Asymp. sig. $=0.000$

Source: own survey computation result, 2018.

commercialization of the rural economy and creates many off-farm job opportunities. Furthermore, infrastructure facilities like telecommunication, power supply, and financial institutions (banks, micro-finance) support the marketing activities in the study area by creating good opportunities for teff marketing.

\section{CONCLUSION}

Teff is the most economically important crop in the study area in terms of income generation because it is priced higher than other crops. The teff value chain actors include input suppliers, farmers, local collectors, wholesalers, retailers, and consumers. The supporters of value chain actors include financial institutions (OCSI, banks), district industry and trade, district agriculture offices, and primary cooperatives. During the production, farmers obtain fertilizer, seed, and herbicides used per hectare from the District Agriculture Bureau through development agents. After production, farmers sell the product to local collectors, wholesalers, retailers, and consumers.

The production and marketing constraints encountered by farmers include the shortage of fertilizer, seed supply, price setting, rust, the high price of fertilizer, poor access to extension services; farmers deal with a strong mistrust of buyers, poor capacity of cooperatives, high marketing costs of production and occurrence of disease. Teff traders in the district face double 
taxation, insufficient infrastructure, capital shortage, insufficient access to credit, farmers' reluctance to sell, poor information flow, and bargaining power. Upgrading activities employed by teff producers in the study areas include using improved seed and fertilizers. Teff traders govern price determination and product specification in the teff value chain of the district.

\section{REFERENCE}

Bekabil, F., Befikadu, B., Ruport, S., Tarekegn, B. (2011). "Strengthening the Teff Value Chain in Ethiopia". Mimeo, Agricultural Transformation Agency (ATA): Addis Ababa.

BoDANR (Bureau of District Agriculture and Natural Resource). (2017). Total area of land for teff production, population size, and quantity estimated from hectar of land during the current year. Jimma Arjo: Western Oromia, Ethiopia.

CSA (Central Statistical Agency). (2017). Agricultural sample survey 2016/2017. Report on Area and Production of Major Crops. Addis Ababa, Ethiopia.
Efa, D., Tinsae, D, Tadese, K. (2016). Analysis of teff Value Chain in Bacho and Dawo Districts of South West Shewa, Ethiopia. Am. Res. J. Bus. and Manag.

Hailu, A. (2016). Value chain analysis of vegetables: the case of Ejere District, West Shoa Zone, Oromia National Regional State of Ethiopia (MSc. Thesis, Haramaya University). ILO (International Labor Organization). (2009). Value Chain Development for Decent Work. A practical and conceptual guide, EMP/ENTERPRISE, International Labour Office, Geneva.

Reardon, T., Chen, K., Minten, B., Adriano, L. (2012). The quiet revolution in staple food value chains: Enter the dragon, the elephant, and the tiger. Asian Development Bank.

Sultan, U. (2016). Analysis of wheat value chain: The case of Sinana District, Bale Zone, Oromia Region, Ethiopia. MSc. Thesis, Haramaya University.

UNECA (2009). The African Economic Outlook (AEO) 2009 on Innovation and New Technologies in Africa.

World Bank (2013). Agri-Business in Africa: Removing Barriers to Regional Trade to Food Staples. Washington, DC.

Yamane, T. (1967). Statistics: An Introductory Analysis, 2nd Edition. New York: Harper and Row. 